\title{
Influences of biofilm-associated ciliates on the settlement of marine invertebrate larvae
}

\author{
Jeff Shimeta*, Justin Cutajar, Matthew G. Watson, Thelma Vlamis
}

School of Applied Sciences, RMIT University, Melbourne, Victoria 3083, Australia

\begin{abstract}
Settlement of benthic marine invertebrate larvae often limits recruitment, influencing the structure and dynamics of natural populations as well as biofouling of marine infrastructure, ship hulls, and aquaculture operations. Certain microbial components of substratum biofilms influence settlement (e.g. bacteria, diatoms), but the importance of biofilm protozoa has been unknown. We tested for effects of ciliates by comparing settlement and survival of common fouling invertebrates among 3 biofilm conditions: no biofilm, a purely bacterial biofilm, and a biofilm of bacteria and ciliates. With an assemblage of 7 ciliates (from Hypotrichia, Haptoria, and Scuticociliatia), the serpulid polychaete Galeolaria caespitosa showed a 44 to $49 \%$ average reduction in settlement rate compared to the purely bacterial biofilm, and post-settlement mortality increased 7 -fold to $34 \%$. In contrast, settlement and survival of the bryozoan Bugula neritina were unaffected. With a partially different assemblage of 11 ciliates (from Hypotrichia, Stichotrichia, Haptoria, Colpodida, and Scuticociliatia), settlement of the serpulid Pomatoceros taeniata more than doubled, whereas that of the blue mussel Mytilus galloprovincialis was reduced by $54 \%$ compared to the purely bacterial biofilm. The results could not be explained by ciliates changing the total abundance of biofilm bacteria. We hypothesize that mechanisms could include direct interactions between larvae and ciliates (physical interactions, interference from ciliates' feeding currents, or responses to chemicals from ciliates), or indirect effects from ciliates altering the bacterial assemblage or its settlement cues. Such large and species-specific effects of ciliates on larval settlement and postsettlement mortality might impact invertebrate recruitment rates and species assemblages, especially because biofilm ciliates are highly variable over time and space.
\end{abstract}

*Email: jeff.shimeta@rmit.edu.au

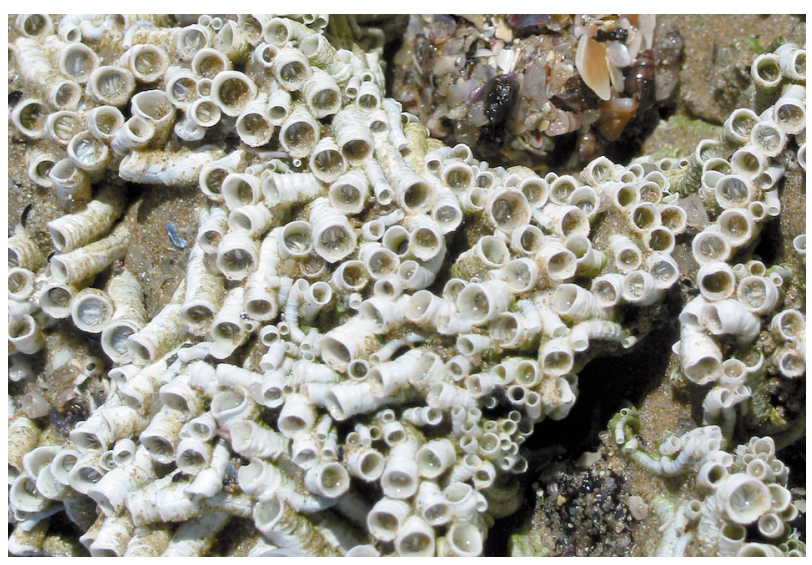

Aggregation of the tubeworm Galeolaria caespitosa. Larval settlement of these and other invertebrates is influenced by ciliates on the substratum.

Photo: J. Shimeta

KEY WORDS: Larval settlement · Ciliates · Biofilm · Biofouling · Galeolaria caespitosa · Pomatoceros taeniata $\cdot$ Mytilus galloprovincialis $\cdot$ Bugula neritina

Resale or republication not permitted without written consent of the publisher

\section{INTRODUCTION}

Most marine benthic invertebrates have a larval stage that disperses in the water column before settling onto a substratum, metamorphosing, and recruiting into the population. The process of larval settlement can be a limiting step for recruitment, ultimately influencing the structure and dynamics of adult populations (Underwood \& Keough 2001). Studies of larval settlement have become key approaches for explaining and predicting patterns and processes in marine assemblages. Particularly 
for sessile species, larval settlement can be the primary determinant of adult distributions (e.g. Raimondi 1991). Understanding the constraints on larval settlement in sessile, hard-substratum species is important not only for studies of general ecology but also in efforts to increase yield in aquaculture industries and to prevent biofouling of marine infrastructure and boat hulls (Qian et al. 2007).

Larvae settle in response to a variety of factors that affect them passively or to which they respond behaviorally. Some of these factors are substratum composition and texture (Berntsson et al. 2000, Qian et al. 2000), hydrodynamic forces (Walters et al. 1997), sediment parameters (Butman 1987), presence of conspecifics (Bryan et al. 1997), presence of a food source or habitat indicator (Daume et al. 2000, Swanson et al. 2006), and microbial biofilms (Qian et al. 2007).

Biofilms are complex 3-dimensional structures composed of microorganisms and a matrix of their extracellular polymers that cover nonliving substrata as well as macrofauna and macroflora (Dobretsov 2010). The development of a biofilm typically follows a succession from adsorption of dissolved chemicals to colonization by prokaryotes and eventually eukaryotes (Wahl 1989, Arndt et al. 2003). When fully developed, the microorganisms in biofilms typically include bacteria, diatoms, thraustochytrids, fungi, and protozoa such as heterotrophic flagellates, amoebae, foraminiferans, heliozoans, and ciliates.

Varied and complex interactions between invertebrate larvae and biofilms have been discovered in recent years (reviewed by Qian et al. 2007). Natural biofilms influence larval settlement in numerous species, having either inductive or inhibitory effects. Early studies showed that these effects vary with general biofilm factors such as age, location, or season of development, but often the biofilm organisms responsible for the influences on settlement were not identified (e.g. Todd \& Keough 1994, Keough \& Raimondi 1995, Wieczorek et al. 1996). More recently, settlement has been shown to relate to the presence of certain taxa of microorganisms, by either correlation or experimental demonstration. These taxa include bacteria (Dobretsov \& Qian 2006, Bao et al. 2007, Hung et al. 2007), diatoms (Harder et al. 2002a, Lam et al. 2003), and thraustochytrids (Raghukumar et al. 2000). Some metabolites and extracellular polymers of bacteria and diatoms have been isolated and identified as the cues to which various invertebrate larvae respond (Harder et al. 2002b, Lau et al. 2003, Lam et al. 2005, Patil \& Anil 2005, Hung et al. 2009).
Despite increasing recognition that larvae respond to specific microorganisms and cues in biofilms and the fact that protozoa are ubiquitous and influential in biofilms, no published studies have investigated the effects of protozoa on larval settlement. Protozoans in biofilms can have strong impacts on bacterial abundances and spatial heterogeneity, bacterial and microalgal species assemblages, biofilm architecture, and sloughing dynamics (Jackson \& Jones 1991, McCormick 1991, Arndt et al. 2003, Parry 2004, Parry et al. 2007). The diverse protozoans in biofilms have complex trophic interactions, seasonal variations, successional dynamics, and constraints from the flow regime and other environmental factors (Franco et al. 1998, Sekar et al. 2002, Arndt et al. 2003, Gong et al. 2005, Wey et al. 2008, Norf et al. 2009, Risse-Buhl \& Küsel 2009). Although the literature on biofilm protozoa is considerable in size, it deals almost entirely with freshwater systems, and relatively little is known about the dynamics of protozoans in marine biofilms. Nonetheless, it is conceivable that biofilm protozoa could influence marine larval settlement, either indirectly by affecting other microorganisms or biofilm conditions that serve as settlement cues, or directly by interacting behaviorally or chemically with larvae.

Other than some general acknowledgments that protozoa are part of the typical biofilm community, the literature on larval settlement includes few remarks on the possible roles of protozoa. In studying the attachment of planula larvae of the sea jelly Cyanea capillata, Brewer (1976) noted that his settlement dishes unintentionally contained variable densities of protozoans, which correlated directly with planula attachment rate. However, he speculated that the correlation was spurious in that protozoan abundance probably reflected the abundance of their bacterial prey, and that bacteria were the more likely influence on planula attachment. After observing high postsettlement mortality of didemnid ascidians on settling panels deployed in the field, Todd \& Keough (1994) noted that the dead juveniles were infested with ciliates and bacteria, which they speculated might explain the subsequent inhibition of further larval settlement. Wieczorek et al. (1995) found the effects of biofilms to shift from inhibitory to stimulatory for barnacle settlement as the biofilms aged, corresponding to an increase in overall microbial diversity and abundances of protozoans, but they did not attempt to isolate the effects of the protozoans themselves.

This is the first study to test for effects of biofilm protozoa on invertebrate larval settlement. We conducted still-water, no-choice laboratory settlement 
assays to compare settlement and survival rates on biofilms in the presence and absence of a mixedspecies assemblage of ciliates. We tested a range of common, hard-substratum, fouling invertebrate species from 3 phyla. The serpulid polychaete tubeworms Galeolaria caespitosa and Pomatoceros taeniata have not been studied previously for biofilm cues in larval settlement, although biofilms are known to stimulate settlement in the congener $P$. lamarckii (Hamer et al. 2001), and the related serpulid $\mathrm{Hy}_{\mathrm{-}}$ droides elegans is among the most extensively studied marine invertebrate in this regard (e.g. Lam et al. 2005 and references therein). G. caespitosa is a gregarious settler that forms dense reef-like mats on intertidal rocks (Minchinton 1997), whereas populations of $P$. taeniata consist of sparser, prostrate tubes. The blue mussel Mytilus galloprovincialis (previously considered a subspecies of $M$. edulis, Gosling 1994) is a common aquaculture species, and its larval settlement is stimulated by biofilms (Bao et al. 2007). The cosmopolitan, arborescent bryozoan Bugula neritina is also known to respond to biofilm cues (Dobretsov \& Qian 2006), but it differs from the other species we tested by having a briefer, nonfeeding larval stage that is considered a relatively indiscriminate settler (Dahms et al. 2004).

\section{MATERIALS AND METHODS}

\section{Biofilm bacteria and ciliates}

Bacteria and ciliates were cultured from natural biofilms that were grown in the subtidal zone at Williamstown, Port Phillip Bay, Australia. Plastic petri-dish microscope slides (Analyslide ${ }^{\mathrm{TM}}$, Pall) were deployed for $2 \mathrm{wk}$ on a panel hung under a pier, after which they were capped and returned to the laboratory for immediate processing.

A presumably mixed assemblage of bacteria was isolated from the slides by scraping off the biofilm, dispersing bacteria by sonicating for $5 \mathrm{~s}$ (Branson Ultrasonics $200 \mathrm{~W}$ at $27 \%$ intensity), and passing the suspension through a $0.8 \mu \mathrm{m}$ pore-size filter to remove debris and larger organisms. These bacteria were then cultured at $4^{\circ} \mathrm{C}$ in $0.2 \mu \mathrm{m}$ filtered and autoclaved sea water (FSW) with $0.005 \%$ yeast extract.

The abundance of motile, non-stalked ciliates on the biofilms grown in the field was determined by counting cells under a dissecting microscope (352 \pm 17 cells cm${ }^{-2}, \mathrm{n}=10$ ). Surface-associated, motile ciliates were isolated by micropipette into monoclonal cultures and inoculated with the mixed assemblage of biofilm bacteria as a food source. Thus, all cultured ciliates were bacterivorous. Ciliates were cultured at $20^{\circ} \mathrm{C}$ in $\mathrm{FSW}$ with $0.005 \%$ yeast extract and rice grains. Ciliates were identified after preserving in Bouin's fixative and staining with protargol (Montagnes \& Lynn 1987), following keys in Lee et al. (2000) and Carey (1992). Seven species were established in culture and used in experiments with Galeolaria caespitosa and Bugula neritina (Table 1). Subsequently, the 2 hypotrich cultures collapsed, and a second field collection yielded 5 more ciliate isolates that were added to the collection for use in experiments with Pomatoceros taeniata and Mytilus galloprovincialis (Table 1).

\section{Invertebrate larvae}

Adults of the serpulid polychaete Galeolaria caespitosa were collected from the intertidal zone at Williamstown, Port Phillip Bay. Spawning was stimulated in the laboratory by gently crushing the tubes in FSW. Eggs from 2 to 3 females were combined with a diluted suspension of sperm from 4 to 5 males. After $24 \mathrm{~h}$, the trochophore larvae were rinsed over a $38 \mu \mathrm{m}$ sieve and transferred to fresh FSW, fed the flagellate Isochrysis sp. (Australian National Algae Culture Collection CS-177, cultured on F/2 medium), at $1 \times 10^{4}$ cells ml ${ }^{-1}$, and maintained at $20^{\circ} \mathrm{C}$ on a 15:9 h light:dark cycle. On a daily basis, larvae were rinsed gently over a sieve, transferred to new FSW, and fed. The settlement assay was begun when larvae displayed behavior of settlement competency (i.e. demersal swimming and exploring) at $7 \mathrm{~d}$ of age, when they were $200 \mu \mathrm{m}$ in length. A final rinse with FSW was done over a $63 \mu \mathrm{m}$ sieve before the settlement assay.

Colonies of the gymnolaemate bryozoan Bugula neritina were collected from settling plates under the pier at Williamstown and held in an aquarium at $20^{\circ} \mathrm{C}$ in the dark. After $48 \mathrm{~h}$, the colonies were exposed to bright light, which stimulated them to release larvae within $1 \mathrm{~h}$. The nonfeeding, coronate larvae $(175 \mu \mathrm{m})$ were competent for settlement upon release from the colonies. The larvae were immediately rinsed over a $63 \mu \mathrm{m}$ sieve with FSW and used in the settlement assay.

Adults of the serpulid polychaete Pomatoceros taeniata were collected from settling plates hung under St. Kilda Pier in Port Phillip Bay. Worms were spawned in several petri dishes of FSW, each containing 2 females and 1 male that released gametes when removed from their tubes. After $15 \mathrm{~min}$, the fer- 
Table 1. Ciliates isolated into pure culture from field-grown biofilms and used in larval settlement assays. Classification follows Lee et al. (2000). Two stichotrichians could not be identified further

\begin{tabular}{|c|c|c|c|c|c|c|}
\hline \multirow{2}{*}{$\begin{array}{l}\text { Subclass } \\
\text { or Order }\end{array}$} & \multirow[t]{2}{*}{ Species } & \multirow{2}{*}{$\begin{array}{c}\text { Cell size } \\
(\mu \mathrm{m})\end{array}$} & \multicolumn{4}{|c|}{ - Used in experiment with: } \\
\hline & & & $\begin{array}{l}\text { Galeolaria } \\
\text { caespitosa }\end{array}$ & $\begin{array}{l}\text { Bugula } \\
\text { neritina }\end{array}$ & $\begin{array}{l}\text { Pomatoceros } \\
\text { taeniata }\end{array}$ & $\begin{array}{c}\text { Mytilus } \\
\text { galloprovincialis }\end{array}$ \\
\hline \multirow[t]{4}{*}{ Hypotrichia } & Diophrys oligothrix & 150 & $\bullet$ & $\bullet$ & & \\
\hline & Euplotes arenularum & 50 & & & $\bullet$ & $\bullet$ \\
\hline & Euplotes elegans & 60 & & & $\bullet$ & $\bullet$ \\
\hline & Euplotes minuta & 50 & $\bullet$ & $\bullet$ & & \\
\hline \multirow[t]{2}{*}{ Stichotrichia } & Amphisiella sp. & 50 & & & - & • \\
\hline & Unidentified spp. (2) & 60 & & & $\bullet$ & $\bullet$ \\
\hline Haptoria & Litonotus sp. & 105 & $\bullet$ & $\bullet$ & $\bullet$ & $\bullet$ \\
\hline Colpodida & Colpoda sp. & 35 & & & $\bullet$ & $\bullet$ \\
\hline \multirow[t]{4}{*}{ Scuticociliatia } & Cyclidium sp. & 40 & $\bullet$ & - & $\bullet$ & - \\
\hline & Protocruzia sp. & 40 & $\bullet$ & $\bullet$ & $\bullet$ & $\bullet$ \\
\hline & Pseudocohnilembus sp. & 35 & - & $\bullet$ & - & • \\
\hline & Uronema sp. & 40 & $\bullet$ & $\bullet$ & $\bullet$ & $\bullet$ \\
\hline
\end{tabular}

tilized eggs were rinsed over a $25 \mu \mathrm{m}$ mesh sieve to remove sperm and transferred to fresh FSW with gentle aeration. After $24 \mathrm{~h}$, larvae reached the trochophore stage and were fed a mixture of Isochrysis sp. (described above) and Pavlova lutherii (Australian National Algae Culture Collection CS-182, cultured on F/2 medium), at $1.5 \times 10^{5}$ cells ml ${ }^{-1}$. Larvae were maintained at $20^{\circ} \mathrm{C}$ on a $15: 9 \mathrm{~h}$ light:dark cycle with gentle aeration and daily feeding and changes of water (using a $63 \mu \mathrm{m}$ sieve after Day 5). The settlement assay was begun at $14 \mathrm{~d}$ of age, when larvae were in the metatrochophore stage (cf. McDougall et al. 2006) and were $250 \mu \mathrm{m}$ long.

Pediveliger larvae of the mussel Mytilus galloprovincialis were obtained at an age of $22 \mathrm{~d}$ from the Victorian Shellfish Hatchery, Dept. of Primary Industries, Queenscliff. The larvae were held at $20^{\circ} \mathrm{C}$ on a 15:9 h light:dark cycle and fed a mixture of algae obtained from the hatchery (Isochrysis sp., Pavlova lutherii, Chaetoceros muelleri, and C. calcitrans) at $5 \times 10^{4}$ cells $\mathrm{ml}^{-1}$. The larvae were rinsed over a $125 \mu \mathrm{m}$ sieve and transferred to new FSW every second day, and their food was replenished twice daily. The settlement assay was begun at $25 \mathrm{~d}$ of age, when the larvae were $350 \mu \mathrm{m}$ long.

\section{Larval settlement assays}

Settlement assays were run separately for each invertebrate species. Assays were run in $55 \mathrm{~mm}$ diameter polystyrene petri dishes with 3 treatments and 8 replicate dishes of each: (1) untreated (i.e. no biofilm), (2) a thin biofilm of bacteria in a monolayer on the dish, and (3) the same monolayer bacterial biofilm plus a mixed assemblage of ciliates. Comparison of larval settlement between the bacterial biofilm treatment and the same biofilm plus ciliates revealed whether there was an effect of ciliates on settlement. Comparison of settlement in the absence of a biofilm and in the presence of the purely bacterial biofilm revealed any influence of the bacteria on settlement. This latter comparison was included in the design to evaluate whether any decline of bacterial density during the assays caused by ciliate grazing could explain observed effects on settlement. We did not include a treatment of ciliates without a bacterial biofilm because many of these surface-associated bacterivorous ciliates (Table 1) would require substratum bacteria in order to engage in natural behaviors of movement and foraging. Therefore, bacteria were included to induce normal ciliate behavior and were not intended to represent a natural bacterial biofilm; indeed, they comprised only cultivable bacteria rather than a complete assemblage of all bacteria from the field.

The monolayer bacterial biofilm was grown by incubating the bottom halves of the petri dishes for $24 \mathrm{~h}$ at $20^{\circ} \mathrm{C}$ in an aerated bath of FSW with $0.001 \%$ yeast extract and $0.001 \%$ bacto-peptone, inoculated with the mixed assemblage of biofilm bacteria isolated from the field. These biofilms developed consistently with an abundance of (2 to 3$) \times 10^{4}$ cells $\mathrm{cm}^{-2}$, 
as measured by epifluorescence microscopy (see below). After growing the biofilms, all petri dishes (as well as untreated dishes) were gently rinsed and filled with FSW. A mixture of cultured ciliates (Table 1) was added to the ciliate treatment dishes to yield 350 cells $\mathrm{cm}^{-2}$ on the bottom (matching the abundance measured on the $2 \mathrm{wk}$ old biofilms collected from the field). The mixture included equal parts from each ciliate culture, although the cultures differed in their cell abundances. The total volume of liquid in each dish was $12 \mathrm{ml}$.

Settlement assays were begun by adding 20 larvae to each dish of every treatment immediately after adding ciliates to the ciliate treatment dishes. The dishes were randomly intermixed in an array on a benchtop during the assay. Each assay was run at the same temperature and light:dark cycle at which the larvae were held prior to the experiment. Dishes with Galeolaria caespitosa and Pomatoceros taeniata were placed on white paper to stimulate settlement, but dishes with Mytilus galloprovincialis were not. Dishes with Bugula neritina were kept in the dark. At 2 time points, all dishes were examined under a dissecting microscope, and larvae were scored as either settled, not settled, or dead. Larvae of $G$. caespitosa, $P$. taeniata, and $B$. neritina were scored as settled if an attachment to the dish was evident. Larvae of $M$. galloprovincialis were considered settled if they were motionless on the bottom, no velum was visible through the shell, and they did not move when the dish was gently agitated. The total length of the assays varied according to the rapidity with which each species settled. The time points for examination were $48 \mathrm{~h}$ and $72 \mathrm{~h}$ for G. caespitosa and P. taeniata, $1 \mathrm{~h}$ and $24 \mathrm{~h}$ for $B$. neritina, and $24 \mathrm{~h}$ and $48 \mathrm{~h}$ for M. galloprovincialis. After the second time point, the abundance of ciliates on the bottoms of the dishes was determined by counting them under a dissecting microscope. The contents of all dishes were then gently decanted and replaced with $1 \%$ formalin in FSW to preserve the biofilm bacteria.

Bacterial densities on the bottoms of the petri dishes were determined by removing the formalin, adding $50 \mu$ l of DAPI solution (0.02 $\left.\mathrm{mg} \mathrm{ml}^{-1}\right)$ and a $22 \times 40 \mathrm{~mm}$ coverglass, and counting cells at $1000 \times$ magnification using oil immersion on an epifluorescence microscope with UV excitation (340-380 nm).

Settlement rates and mortality rates (both as arcsine square-root transformed proportions) were tested at each time point by an a priori test of main effects (for the effect of the treatments, i.e. the between-subjects factor) using the MSE from a repeated-measures analysis of variance (ANOVA). If the effect of the treatment was significant at $\alpha=$ 0.05, Tukey pairwise comparisons were run among the treatments at that time point using the MSE from the test of main effects. The biofilm bacterial densities at the end of each assay were tested for differences among the 3 treatments by 1-way ANOVA, followed by Tukey pairwise comparisons. All statistical tests were run on Systat v5.2.1 for Macintosh.

\section{RESULTS}

\section{Galeolaria caespitosa}

After $48 \mathrm{~h}$, the proportion of larvae that had settled and survived differed significantly among the treatments ( $\mathrm{p}<0.01$; Fig. 1A). Settlement was enhanced in the presence of a pure bacterial biofilm compared to the untreated dishes $(p<0.01)$. Settlement in the presence of ciliates and bacteria was $49 \%$ lower than in the pure bacterial biofilm $(p=0.041)$ and not different from the untreated dishes $(\mathrm{p}=0.64)$. There was ca. $5 \%$ post-settlement mortality (proportion of settled larvae that had died), but it did not differ among treatments ( $p=0.88$; Fig. 1A). The total proportion of settled larvae (including live and dead) therefore had a similar pattern to the settled live larvae ( $p=0.013$ for the main effect), although the $48 \%$ decline in the presence of ciliates compared to the pure bacterial biofilm was only marginally close to significant at $\mathrm{p}=0.081$ (Fig. 1A).

After $72 \mathrm{~h}$, the settled live larvae showed a similar enhancement in the pure bacterial biofilm compared to the untreated dishes $(\mathrm{p}<0.001$ for both the main effect and the comparison; Fig. 1B). There was also a $44 \%$ reduction of live settlers in the biofilm with ciliates compared to the pure bacterial biofilm ( $p<$ 0.001). Post-settlement mortality in the treatment with ciliates, however, increased dramatically to $34 \%$, whereas it remained at ca. $5 \%$ in the other treatments ( $p<0.01$ for the main effect). Thus, there was a 7 -fold increase in mortality rate associated with the presence of ciliates. As a result, the total proportion of settlers (live and dead) differed among the treatments $(\mathrm{p}<0.01)$ : it was similar in the 2 biofilm treatments (with and without ciliates, $\mathrm{p}=0.41$ ), and approximately twice the settlement in the untreated dishes $(\mathrm{p}<0.01$ for the pure bacterial biofilm and $\mathrm{p}=$ 0.042 for the bacteria+ciliates treatment).

At the end of the assay (72 h), there was no difference in the abundance of biofilm bacteria between 

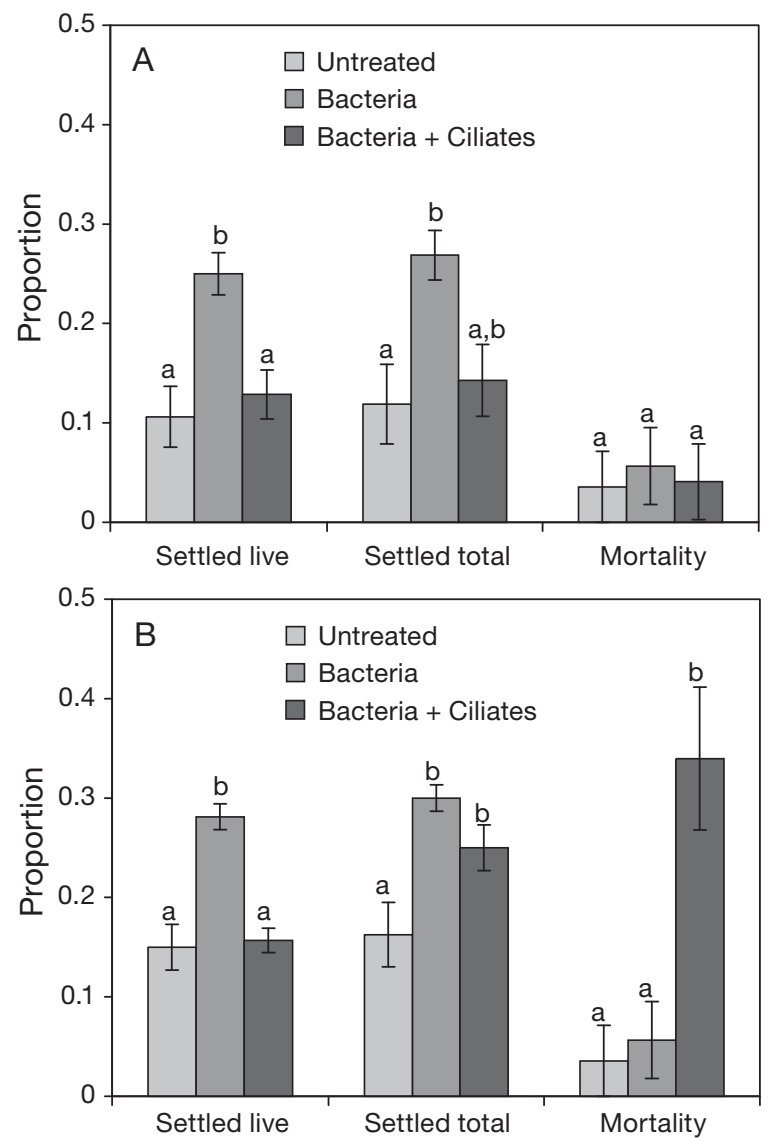

Fig. 1. Galeolaria caespitosa. Settlement assay with larvae. 'Settled live' is the proportion of attached, live larvae among the total number of larvae added to the dish. 'Settled total' is the analogous proportion including all attached larvae, both live and dead. 'Mortality' is the proportion of attached, dead larvae among the total number of attached larvae (hence, post-settlement mortality). Bars show mean $\pm \mathrm{SE}$, and shading indicates treatments of the petri dishes ('Untreated' had no biofilm; 'Bacteria' had only a bacterial biofilm; 'Bacteria + Ciliates' had the same bacterial biofilm plus ciliates). Within each category on the abscissa, means with different letters are significantly different at $\alpha=0.05$. (A) $48 \mathrm{~h}$ tests of main effects (for the treatments): settled live $\mathrm{p}=0.0044$, settled total $\mathrm{p}=0.013$, mortality $\mathrm{p}=0.88$. (B) $72 \mathrm{~h}$ tests of main effects: settled live $p<0.001$, settled total $p=0.0022$, mortality $\mathrm{p}=0.0011$ the bacteria treatment and the bacteria+ciliates treatment ( $p=0.80 ;$ Table 2). The untreated dishes had some bacterial growth on the bottom, but it was only $28 \%$ of the abundance in the 2 biofilm treatments $(\mathrm{p}<0.001$ in both cases). The bacteria+ciliate dishes had $378 \pm 30$ ciliates $\mathrm{cm}^{-2}$, whereas no ciliates were detected in the other treatments.

\section{Bugula neritina}

Many of the Bugula neritina larvae settled on the sides of the petri dishes. Because the dishes had been fully submerged in the bacterial bath for growing the biofilms, we assume that bacteria grew on the sides as well as on the bottoms. We examined the sides of the dishes for ciliates in the bacteria+ciliates treatment, finding ciliates to be in similar abundance on the side and the bottom.

After $1 \mathrm{~h}$, settlement was significantly lower in the 2 biofilm treatments (with and without ciliates) compared to the untreated dishes $(p<0.001$ for the main effect and for both comparisons; Fig. 2A). There was no difference between the 2 biofilm treatments $(\mathrm{p}=$ $0.14)$, i.e. the presence of ciliates had no significant effect on settlement. After $24 \mathrm{~h}$, the pure bacterial biofilm still had a significantly lower settlement than the untreated dishes $(\mathrm{p}<0.01$ for both the main effect and the comparison), but no other comparisons were statistically significant ( $\mathrm{p}>0.05)$. Thus, the treatment with ciliates was not different from any other treatments. There was no mortality in the assay.

At the end of the assay ( $24 \mathrm{~h})$, there was no difference in the abundance of biofilm bacteria between the bacteria treatment and the bacteria+ciliates treatment ( $p=0.34$; Table 2 ). The abundance of bacteria in the untreated dishes was an order of magnitude lower than that in the 2 biofilm treatments ( $\mathrm{p}<$ 0.001 in both comparisons). The bacteria+ciliate dishes had $342 \pm 30$ ciliates $\mathrm{cm}^{-2}$, whereas no ciliates were detected in the other treatments.

Table 2. Biofilm bacterial densities (mean $\pm \mathrm{SE}$ cells $\mathrm{cm}^{-2}$ ) at the end of each larval settlement assay. 'Untreated' petri dishes were not subjected to biofilm growth prior to the assay. 'Bacteria' and 'Bacteria + Ciliates' petri dishes were incubated in a bacterial culture prior to the assay. Only 'Bacteria + Ciliates' petri dishes had ciliates added at the start of the assay. Means with different superscripts were significantly different by post hoc multiple comparison tests following a significant 1-way analysis of variance $(\alpha=0.05)$

\begin{tabular}{|c|c|c|c|}
\hline Larval assay & Untreated $\left(\times 10^{3}\right)$ & Bacteria $\left(\times 10^{4}\right)$ & Bacteria + Ciliates $\left(\times 10^{4}\right)$ \\
\hline Galeolaria caespitosa & $7.82 \pm 0.61^{\mathrm{a}}$ & $2.91 \pm 0.20^{\mathrm{b}}$ & $2.62 \pm 0.21^{\mathrm{b}}$ \\
\hline Bugula neritina & $1.92 \pm 0.41^{\mathrm{a}}$ & $1.48 \pm 0.09^{b}$ & $1.63 \pm 0.08^{b}$ \\
\hline Pomatoceros taeniata & $6.97 \pm 0.56^{\mathrm{a}}$ & $2.52 \pm 0.15^{\mathrm{b}}$ & $1.89 \pm 0.15^{\mathrm{c}}$ \\
\hline Mytilus galloprovincialis & $2.94 \pm 0.20^{\mathrm{a}}$ & $2.19 \pm 0.10^{\mathrm{b}}$ & $1.96 \pm 0.12^{\mathrm{b}}$ \\
\hline
\end{tabular}



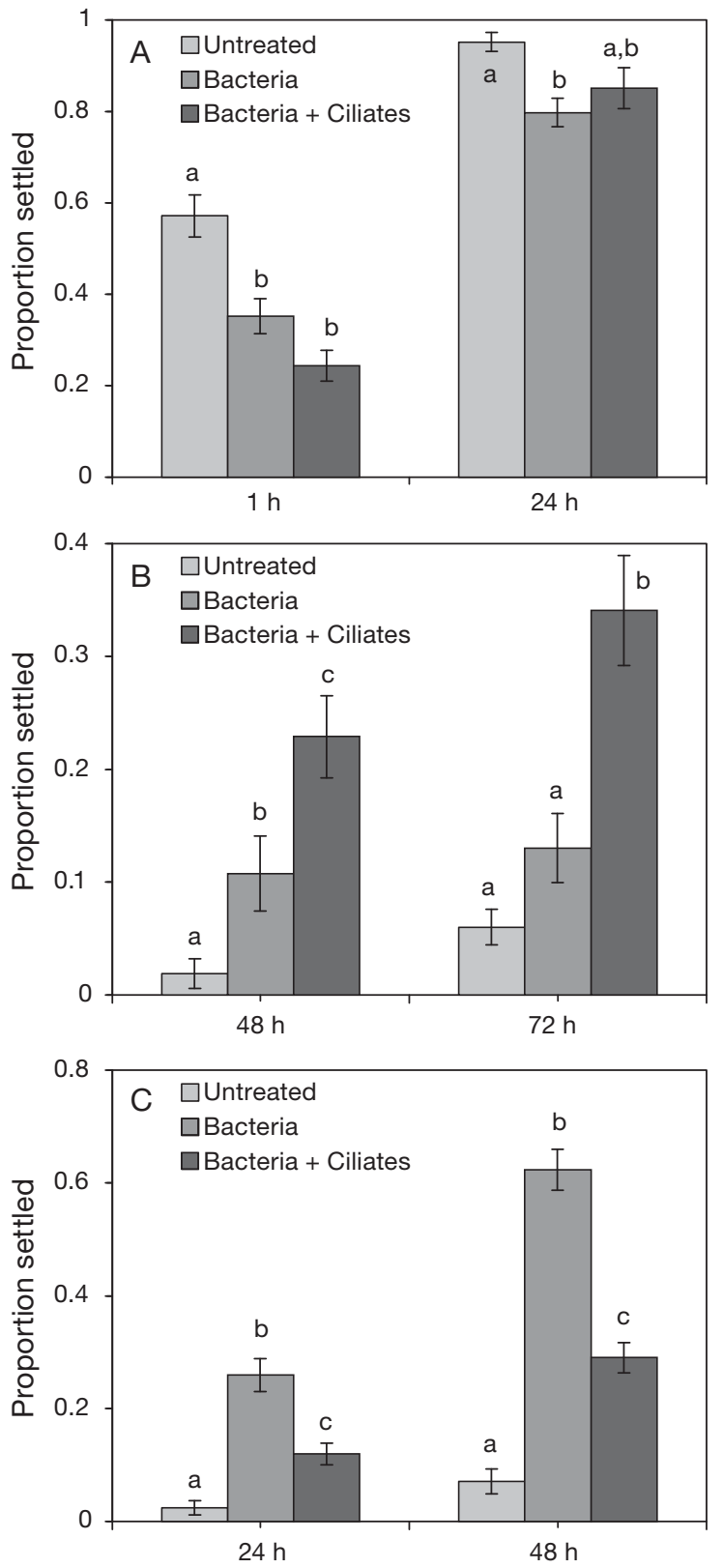

Fig. 2. Proportion of settled larvae (mean \pm SE) in assays. Treatments indicated by shading are as in Fig. 1. Within each category on the abscissa, means with different letters are significantly different at $\alpha=0.05$. Tests of main effects (for the treatments) as follows: (A) Bugula neritina, $1 \mathrm{~h}: \mathrm{p}<$ 0.001, $24 \mathrm{~h}: \mathrm{p}=0.0057$. (B) Pomatoceros taeniata, $48 \mathrm{~h}$ : $\mathrm{p}<0.001,72 \mathrm{~h}: \mathrm{p}<0.001$. (C) Mytilus galloprovincialis, $24 \mathrm{~h}$ : $\mathrm{p}<0.001,48$ h: $\mathrm{p}<0.001$

\section{Pomatoceros taeniata}

At both time points, the proportion of larvae that had settled was significantly different among the treatments ( $p<0.001$; Fig. 2B). There was negligible mortality at $72 \mathrm{~h}$, and it did not differ among treatments $(p=0.61$, data not shown). At $48 \mathrm{~h}$, settle- ment on the pure bacterial biofilm was significantly greater than on the untreated dishes $(p=0.034)$, but at $72 \mathrm{~h}$ they were not significantly different $(\mathrm{p}=0.26)$. At both time points, the presence of ciliates increased settlement significantly compared to the pure bacterial biofilm ( $p=0.038$ at $48 \mathrm{~h}$ and $p<0.001$ at $72 \mathrm{~h}$ ), by an average of 2.4 -fold.

By the end of the assay, the abundance of biofilm bacteria was $25 \%$ lower in the presence of ciliates than in the pure bacterial biofilm treatment $(p<0.01$; Table 2), presumably as a result of ciliate grazing. There was slight growth of bacteria in the untreated dishes, but it was significantly less than the bacteria in the other treatments $(p<0.001$ in both cases). The bacteria+ciliate dishes had $356 \pm 29$ ciliates $\mathrm{cm}^{-2}$, whereas no ciliates were detected in the other treatments.

\section{Mytilus galloprovincialis}

At both time points, the proportion of settled larvae was significantly different among all treatments $(\mathrm{p}<$ 0.001), showing the same pattern in each case (Fig. 2C). The presence of a pure bacterial biofilm enhanced settlement by an average of 9.8 -fold compared to the untreated dishes $(\mathrm{p}<0.001$ at both time points). Settlement in the presence of ciliates was reduced to $46 \%$ of settlement in the pure bacterial biofilm ( $p<0.001$ at both time points). There was no mortality in any of the treatments.

At the end of the assay ( $48 \mathrm{~h}$ ), there was no difference in the abundance of biofilm bacteria between the bacteria treatment and the bacteria+ciliates treatment $(p=0.19$; Table 2$)$. The slight growth of bacteria in the untreated dishes was an order of magnitude less than in the 2 biofilm treatments $(\mathrm{p}<0.001$ in both cases). The bacteria+ciliate dishes had $432 \pm$ 28 ciliates $\mathrm{cm}^{-2}$, whereas no ciliates were detected in the other treatments.

\section{DISCUSSION}

\section{Effects of ciliates on larval settlement}

We observed a variety of responses among invertebrate species to the presence of ciliates in the biofilm, including inhibition of settlement, facilitation of settlement, enhanced post-settlement mortality, and no response. There are several possible mechanisms that could be involved in these effects. Here we present hypotheses that require further investigation to substantiate. 
A possible mechanism for the $50 \%$ reductions of settlement rate in Galeolaria caespitosa and Mytilus galloprovincialis is direct interference from ciliates near the substratum, e.g. through behavioral interactions or if the ciliates' feeding currents interrupt the swimming or crawling of larvae as they test the substratum. The ciliates in these experiments (Table 1) included strongly thigmotactic species that crawl and cling tightly to the substratum (e.g. hypotrichs such as Diophrys oligothrix and Euplotes spp.) and epibenthic species that glide on the substratum and periodically swim above it (e.g. scuticociliates such as Cyclidium sp. and Uronema sp.; Patterson et al. 1989). These ciliates graze on attached bacteria and/or suspension feed. The largest ciliates in our experiments were up to 30 to $75 \%$ of the size of larval G. caespitosa and M. galloprovincialis, which might allow the ciliates' movements to interfere with larvae. The feeding currents of these types of ciliates can be up to $0.2 \mathrm{~mm} \mathrm{~s}^{-1}$ in the vicinity of the cells and $1 \mathrm{~mm} \mathrm{~s}^{-1}$ near their cilia (Fenchel 1986, Shimeta et al. 2001), which might disrupt slowly swimming pediveligers moving at speeds of ca. $0.6 \mathrm{~mm} \mathrm{~s}^{-1}$ (Cragg 1980). Polychaete larvae are less likely to be disrupted because of their faster swimming speeds, e.g. $4 \mathrm{~mm} \mathrm{~s}^{-1}$ in metatrochophores of G. caespitosa (Bolton $\&$ Havenhand 1997). Once larvae are crawling on the substratum, they could be more easily affected by ciliate movements and currents. Another possibility for a direct interaction is the release of a chemical cue by ciliates that deters settlement, similar to negative cues released by some bacteria and algae (Lau \& Qian 1997, Rao et al. 2007).

Another possible mechanism for the settlement inhibition in Galeolaria caespitosa and Mytilus galloprovincialis is indirect via an influence of ciliates on biofilm bacteria, because the pure bacterial biofilm did stimulate settlement in these invertebrates compared to the untreated dishes. Ciliates did not change the total bacterial abundance, however, so the settlement inhibition cannot be explained as a response to total bacterial density. It is possible that grazing altered the abundances of certain bacterial species that serve as settlement cues, either enhancing species that are negative cues or reducing species that are positive cues. We cannot evaluate this hypothesis from our results, however, because we did not characterize the bacterial assemblage and therefore do not know if it shifted in response to the presence of ciliates. It is well known that some bacteria serve as settlement inducers while others are inhibitors (Qian et al. 2007), and that settlement responses of invertebrates can vary depending on the bacterial species assemblage in a biofilm (Lau et al. 2005). Protozoans have large grazing impacts on biofilm bacterial abundances and biofilm structure, although this is primarily known for freshwater systems rather than marine (Arndt et al. 2003, Parry 2004), and there is little information on grazing effects on the bacterial species assemblages in biofilms. Another possible indirect effect from protozoan grazing could be that larval settlement is inhibited by bacterial metabolites released as a chemical defense against grazing (Matz et al. 2008). Finally, chemicals released by ciliates might cause changes in the bacterial species assemblage, similar to algal metabolites that have been shown to influence the bacterial community on their surfaces (Steinberg et al. 2002). We note that the mechanism of settlement inhibition was not necessarily the same for G. caespitosa and M. galloprocinvialis, particularly because these species were exposed to partially differing assemblages of ciliates.

The second type of negative effect from ciliates on larval settlement was post-settlement mortality in Galeolaria caespitosa, which affected $30 \%$ of the settlers. Possible mechanisms include a direct physical interference from ciliates or a noxious chemical released by ciliates or bacteria in the biofilm. We observed dense aggregations of ciliates around dead larvae, similar to Todd \& Keough's (1994) observations around dead ascidian settlers, which could reflect a direct interference from ciliates that killed the settled larvae. We do not know, however, whether these ciliates caused the mortality or were attracted to the carcasses afterward. Early post-settlement mortality can be a large and important factor determining recruitment success in marine invertebrates (Hunt \& Scheibling 1997). It has a variety of known causes, but this is the first demonstration of mortality associated with the presence of ciliates.

The positive influence of ciliates on settlement rate in Pomatoceros taeniata (more than a doubling) could have been caused by a stimulatory cue, e.g. larvae responding to the presence of ciliates as a food source or to a stimulatory chemical released by ciliates. We observed numerous ciliates crawling over the tubes of newly settled $P$. taeniata, which might reflect a facilitative relationship. In this assay, the ciliates reduced the bacterial abundance presumably by grazing, but since the bacteria had a stimulatory effect on settlement (at one of the 2 time points), a loss of total bacterial abundance by grazing cannot account for the increased settlement rate. We cannot exclude, however, that grazing altered the bacterial assemblage, which in turn stimulated settlement. 
We caution against concluding from our results that the 2 serpulid polychaetes (Galeolaria caespitosa and Pomatoceros taeniata) have opposite responses to ciliates in general, because they were tested using partially differing assemblages of ciliates. P. taeniata and Mytilus galloprovincialis, however, were tested with the same assemblage of ciliates and showed opposite responses (facilitation and inhibition, respectively). These results could reflect differential responses to one or more ciliate species, but we cannot exclude that any differences in the bacterial assemblage between these assays could have induced different larval responses through indirect effects of ciliates on settlement cues from bacteria.

We found no evidence for an effect of ciliates on the settlement or survival of the bryozoan Bugula neritina. Although bryozoan larvae do respond to settlement cues from biofilms, they are considered to be relatively indiscriminate settlers compared to other invertebrates, attributed to their short planktonic phase (Dahms et al. 2004, Dobretsov \& Qian 2006). Unwettable surfaces such as polystyrene dishes are known to stimulate settlement of $B$. neritina larvae (Mihm et al. 1981), which could limit the potential to detect stimulatory cues from ciliates if they exist. However, the significant reduction in settlement caused by the presence of a bacterial biofilm in our experiments would have at least partially removed such a masking effect, and the addition of ciliates to the bacterial biofilm showed no further stimulation of settlement. Taking into account these considerations, the most conservative conclusion is that ciliates caused no inhibitory effects on settlement or survival in B. neritina.

\section{Implications}

Effects of ciliates on larval settlement and survival appear to be highly varied and species specific. Having observed them in 3 of 4 species tested, including mussels and polychaetes, they may be widespread among taxa. Because several mechanisms could be involved, many variables might mediate these interactions in the field to determine their impact on invertebrate population dynamics.

Biofilms in the field are more complex than those we created for our experiments, which included only cultivable strains of bacteria grown in a sparse monolayer. Natural biofilms have more bacterial diversity as well as microalgae and other types of protozoa, and complex 3-dimensional architecture associated with the matrix of bacterial extracellular polymers and microcolonies of cells (Arndt et al. 2003, Dobretsov 2010). Therefore, if any influences of ciliates on larval settlement in our experiments were through an indirect effect on bacteria, further investigations would be needed to determine how these interactions function in a more complex, natural microbial biofilm community.

The nature of the ciliate fauna in a biofilm could also play an important role in the effects on settlement. We used a ciliate assemblage and total density from 2 wk old biofilms from the field; however, the assemblage composition and density are likely to be different in younger or older biofilms. Larvae might respond to certain ciliate species more than others, due to differences in ciliate behavior, grazing impacts, etc. Indeed, the settlement responses we measured might be caused by only certain ciliates in the assemblages we used. Furthermore, these assemblages represented only a subset of ciliates that grew on our settlement slides in the field, and there may be other types that influence settlement differently. We only isolated mobile, easily cultured, bacterivorous species, not herbivores, predators, or attached species such as the stalked peritrichs or suctorians which create strong feeding currents. Ciliates with these different trophic modes could have other effects on the microbial biofilm community and larval settlement, e.g. impacting microalgae that serve as settling cues (e.g. Harder et al. 2002a) or altering the boundary-layer flow field (Fenchel 1986). Any flowmediated interactions between ciliates and larvae might be influenced by the surrounding flow field in nature, which should be considered in future investigations, whereas our experiments were done in still water.

Elucidating the mechanisms by which ciliates influence larval settlement may help to predict settlement patterns in the field and to interpret studies on settlement responses to biofilms. Although ciliates are ubiquitous in marine biofilms, their densities and species assemblages vary seasonally as well as during succession after space is exposed by a disturbance or when a new substratum is introduced to the environment (Anderson 1995, Arndt et al. 2003, Gong et al. 2005). Their species assemblages correlate with environmental parameters (e.g. temperature, salinity, and nutrients; Gong et al. 2005) and therefore are likely to vary spatially among locations or on substrata of different materials (Coppellotti \& Matarazzo 2000), although these aspects of their distribution have received little attention in marine habitats. Based on our results, we hypothesize that recruitment of certain invertebrates onto an available 
patch of substratum can depend on the ciliate fauna present at that point in the succession of the biofilm community. This phenomenon might explain some of the variations of recruitment onto settlement panels in the field in previous studies that neglected to examine protozoa in the biofilms. For example, settlement of various invertebrates has been found to differ among natural biofilms of different ages (Keough \& Raimondi 1995, Bao et al. 2007), grown in different seasons (Wieczorek et al. 1996, Bao et al. 2007), and grown in different locations (Dobretsov \& Qian 2006, Hung et al. 2007). In these studies and others, such effects have been attributed to assumed differences in the general microbial film community or specifically to measured differences in bacteria, but the ciliate assemblages might also have played important roles.

Furthermore, because the settlement responses to ciliates in our experiments differed among invertebrate species, these interactions could play a role in shaping the species assemblage of invertebrates at a site. For example, settlement of Pomatoceros taeniata doubled, whereas that of Mytilus galloprovincialis was halved when exposed to the same assemblage of ciliates (although the bacterial assemblage in the biofilm was not necessarily identical). Based on these results, we hypothesize that a substratum with these ciliates should favor colonization by $P$. taeniata rather than M. galloprovincialis.

Effects of ciliates on settlement rates also have implications for aquaculture and for efforts to reduce invertebrate fouling of marine infrastructure, because of the known importance of biofilms in these systems (Qian et al. 2007). For example, the reduced settlement of Mytilus galloprovincialis suggests that elimination of ciliates from aquaculture ropes could improve settlement rates of cultivated mussels. If an aquaculture species is stimulated to settle by ciliates, seeding the substratum with ciliates might enhance yield. In the field of antifouling research, efforts are increasingly directed toward harnessing natural antifoulant chemicals (Qian et al. 2010), where further research on the mechanisms of settlement inhibition by ciliates might have application.

Acknowledgements. This study was funded by a grant from the Ian Potter Foundation and by RMIT University. We thank A. Scardino and P. Carnell for assistance with field collections, staff at the Victorian Shellfish Hatchery (Dept. of Primary Industries) for providing mussel larvae, J. Carey for advice on statistics, and P. Steinberg, T. Harder, and C. Lutz for fruitful discussions. Comments from 3 anonymous reviewers helped to improve the manuscript.

\section{LITERATURE CITED}

Anderson MJ (1995) Variations in biofilms colonizing artificial surfaces: seasonal effects and effects of grazers. J Mar Biol Assoc UK 75:705-714

Arndt H, Schmidt-Denter K, Auer B, Weitere M (2003) Protozoans and biofilms. In: Krunbein WE, Paterson DM, Zavarzin GA (eds) Fossil and recent biofilms. Kluwer Academic, Dordrecht, p 161-179

$>$ Bao WY, Satuito CG, Yang JL, Kitamura H (2007) Larval settlement and metamorphosis of the mussel Mytilus galloprovincialis in response to biofilms. Mar Biol 150: 565-574

Berntsson KM, Jonsson PR, Lejhall M, Gatenholm P (2000) Analysis of behavioural rejection of micro-textured surfaces and implications for recruitment by the barnacle Balanus improvisus. J Exp Mar Biol Ecol 251:59-83

Bolton TF, Havenhand JN (1997) Physiological versus viscosity-induced effects of water temperature on the swimming and sinking velocity of larvae of the serpulid polychaete Galeolaria caespitosa. Mar Ecol Prog Ser 159: 209-218

Brewer RH (1976) Some microenvironmental influences on attachment behavior of the planula of Cyanea capillata (Cnidaria: Scyphozoa). In: Mackie GO (ed) Coelenterate ecology and behavior. Plenum, New York, NY, p 347-354

Bryan PJ, Qian PY, Kreider JL, Chia FS (1997) Induction of larval settlement and metamorphosis by pharmacological and conspecific associated compounds in the serpulid polychaete Hydroides elegans. Mar Ecol Prog Ser 146: 81-90

Butman CA (1987) Larval settlement of soft-sediment invertebrates: the spatial scales of pattern explained by active habitat selection and the emerging role of hydrodynamical processes. Oceanogr Mar Biol Annu Rev 25:113-165

Carey PG (1992) Marine interstitial ciliates. Chapman \& Hall, London

Coppellotti O, Matarazzo P (2000) Ciliate colonization of artificial substrates in the Lagoon of Venice. J Mar Biol Assoc UK 80:419-427

Cragg SM (1980) Swimming behaviour of the larvae of Pecten maximus (L.) (Bivalvia). J Mar Biol Assoc UK 60: 551-564

Dahms HU, Dobretsov S, Qian PY (2004) The effect of bacterial and diatom biofilms on the settlement of the bryozoan Bugula nertina. J Exp Mar Biol Ecol 313:191-209

> Daume S, Krsinich A, Farrell S, Gervis M (2000) Settlement, early growth and survival of Haliotis rubra in response to different algal species. J Appl Phycol 12:479-488

Dobretsov S (2010) Marine biofilms. In: Durr S, Thomason JC (eds) Biofouling. Wiley-Blackwell, Chichester, p 123-136

- Dobretsov S, Qian PY (2006) Facilitation and inhibition of larval attachment of the bryozoan Bugula neritina in association with mono-species and multi-species biofilm. J Exp Mar Biol Ecol 333:263-274

Fenchel T (1986) Protozoan filter feeding. Prog Protistol 1:65-113

Franco C, Esteban GF, Téllez C (1998) Colonization and succession of ciliated protozoa associated with submerged leaves in a river. Limnologica 28:275-283

> Gong J, Song W, Warren A (2005) Periphytic ciliate colonization: annual cycle and responses to environmental conditions. Aquat Microb Ecol 39:159-170

Gosling EM (1994) Speciation and wide-scale genetic differentiation. In: Beaumont AR (ed) Genetics and evolution 
of aquatic organisms. Chapman \& Hall, London, p 1-15

Hamer JP, Walker G, Latchford JW (2001) Settlement of Pomatoceros lamarckii (Serpulidae) larvae on biofilmed surfaces and the effect of aerial drying. J Exp Mar Biol Ecol 260:113-131

Harder T, Lam C, Qian PY (2002a) Induction of larval settlement in the polychaete Hydroides elegans by marine biofilms: an investigation of monospecific diatom films as settlement cues. Mar Ecol Prog Ser 229:105-112

> Harder T, Lau SCK, Dahms HU, Qian PY (2002b) Isolation of bacterial metabolites as natural inducers for larval settlement in the marine polychaete Hydroides elegans (Haswell). J Chem Ecol 28:2029-2043

> Hung OS, Thiyagarajan V, Zhang R, Wu RSS, Qian PY (2007) Attachment of Balanus amphitrite larvae to biofilms originating from contrasting environments. Mar Ecol Prog Ser 333:229-242

> Hung OS, Lee OO, Thiyagarajan V, He HP and others (2009) Characterization of cues from natural multi-species biofilms that induce larval attachment of the polychaete Hydroides elegans. Aquat Biol 4:253-262

> Hunt HL, Scheibling RE (1997) Role of early post-settlement mortality in recruitment of benthic marine invertebrates. Mar Ecol Prog Ser 155:269-301

Jackson SM, Jones EBG (1991) Interactions within biofilms: the disruption of biofilm structure by protozoa. Kieler Meeresforsch 8:264-268

> Keough MJ, Raimondi PT (1995) Responses of settling invertebrate larvae to bioorganic films: effects of different types of films. J Exp Mar Biol Ecol 185:235-253

> Lam CL, Harder T, Qian PY (2003) Induction of larval settlement in the polychaete Hydroides elegans by surfaceassociated settlement cues of marine benthic diatoms. Mar Ecol Prog Ser 263:83-92

> Lam CL, Harder T, Qian PY (2005) Induction of larval settlement in the polychaete Hydroides elegans by extracellular polymers of benthic diatoms. Mar Ecol Prog Ser 286:145-154

> Lau SCK, Qian PY (1997) Phlorotannins and related compounds as larval settlement inhibitors of the tubebuilding polychaete Hydroides elegans. Mar Ecol Prog Ser 159:219-227

> Lau SCK, Harder T, Qian PY (2003) Induction of larval settlement in the serpulid polychaete Hydroides elegans (Haswell): role of bacterial extracellular polymers. Biofouling 19:197-204

> Lau SCK, Thiyagarajan V, Cheung SCK, Qian PY (2005) Roles of bacterial community composition in biofilms as a mediator for larval settlement of three marine invertebrates. Aquat Microb Ecol 38:41-51

Lee JJ, Leedale GF, Bradbury P (2000) An illustrated guide to the protozoa, 2nd edn. Society of Protozoologists, Lawrence, KS

Matz C, Webb JS, Schupp PJ, Phang SY and others (2008) Marine biofilm bacteria evade eukaryotic predation by targeted chemical defense. PLoS One 3:e2744

McCormick PV (1991) Lotic protistan herbivore selectivity and its potential impact on benthic algal assemblages. J N Am Benthol Soc 10:238-250

> McDougall C, Chen WC, Shimeld SM, Ferrier DEK (2006) The development of the larval nervous system, musculature and ciliary bands of Pomatoceros lamarckii (Annelida): heterochrony in polychaetes. Front Zool 3:16

- Mihm JW, Banta WC, Loeb GL (1981) Effects of adsorbed organic and primary fouling films on bryozoan settle- ment. J Exp Mar Biol Ecol 54:167-179

Minchinton TE (1997) Life on the edge: conspecific attraction and recruitment of populations to disturbed habitats. Oecologia 111:45-52

Montagnes DJS, Lynn DH (1987) A quantitative protargol stain (QPS) for ciliates: method description and test of its quantitative nature. Mar Microb Food Webs 2:83-93

Norf H, Arndt H, Weitere M (2009) Responses of biofilmdwelling ciliate communities to planktonic and benthic resource enrichment. Microb Ecol 57:687-700

Parry JD (2004) Protozoan grazing of freshwater biofilms. Adv Appl Microbiol 54:167-196

> Parry JD, Holmes AK, Unwin ME, Laybourn-Parry J (2007) The use of ultrasonic imaging to evaluate the effect of protozoan grazing and movement on the topography of bacterial biofilms. Lett Appl Microbiol 45:364-370

> Patil JS, Anil AC (2005) Influence of diatom exopolymers and biofilms on metamorphosis in the barnacle Balanus amphitrite. Mar Ecol Prog Ser 301:231-245

Patterson DJ, Larsen J, Corliss JO (1989) The ecology of heterotrophic flagellates and ciliates living in marine sediments. Prog Protistol 3:185-277

> Qian PY, Rittschof D, Sreedhar B (2000) Macrofouling in unidirectional flow: miniature pipes as experimental models for studying the interaction of flow and surface characteristics on the attachment of barnacle, bryozoan and polychaete larvae. Mar Ecol Prog Ser 207:109-121

> Qian PY, Lau SCK, Dahms HU, Dobretsov S, Harder T (2007) Marine biofilms as mediators of colonization by marine macroorganisms: implications for antifouling and aquaculture. Mar Biotechnol 9:399-410

Qian PY, Xu Y, Fusetani N (2010) Natural products as antifouling compounds: recent progress and future perspectives. Biofouling 26:223-234

Raghukumar S, Anil AC, Khandeparker L, Patil JS (2000) Thraustochytrid protists as a component of marine microbial films. Mar Biol 136:603-609

> Raimondi PT (1991) Settlement behavior of Chthamalus anisopoma larvae largely determines the adult distribution. Oecologia 85:349-360

> Rao D, Webb JS, Holmström C, Case R, Low A, Steinberg P, Kjelleberg S (2007) Low densities of epiphytic bacteria from the marine alga Ulva australis inhibit settlement of fouling organisms. Appl Environ Microbiol 73:7844-7852

> Risse-Buhl U, Küsel K (2009) Colonization dynamics of biofilm-associated ciliate morphotypes at different flow velocities. Eur J Protistol 45:64-76

> Sekar R, Nair KVK, Rao VNR, Venugopalan VP (2002) Nutrient dynamics and successional changes in a lentic freshwater biofilm. Freshw Biol 47:1893-1907

Shimeta J, Starczak VR, Ashiru OM, Zimmer CA (2001) Influences of benthic boundary-layer flow on feeding rates of ciliates and flagellates at the sediment-water interface. Limnol Oceanogr 46:1709-1719

Steinberg PD, de Nys R, Kjelleberg S (2002) Chemical cues for surface colonization. J Chem Ecol 28:1935-1951

Swanson RL, de Nys R, Huggett MJ, Green JK, Steinberg PD (2006) In situ quantification of a natural settlement cue and of recruitment in the Australian sea urchin Holopneustes purpurascens. Mar Ecol Prog Ser 314:1-14

> Todd CD, Keough MJ (1994) Larval settlement in hard substratum epifaunal assemblages: a manipulative field study of the effects of substratum filming and the presence of incumbents. J Exp Mar Biol Ecol 181:159-187

Underwood AJ, Keough MJ (2001) Supply-side ecology; the 
nature and consequences of variations in recruitment of intertidal organisms. In: Bertness MD, Gaines SD, Hay ME (eds) Marine community ecology. Sinauer, Sunderland, MA, p 183-200

Wahl M (1989) Marine epibiosis. I. Fouling and antifouling: some basic aspects. Mar Ecol Prog Ser 58:175-189

Walters LJ, Hadfield MG, del Carmen KA (1997) The importance of larval choice and hydrodynamics in creating aggregations of Hydroides elegans (Polychaeta: Serpulidae). Invertebr Biol 116:102-114

Editorial responsibility: Pei-Yuan Qian,

Kowloon, Hong Kong SAR
Wey JK, Scherwass A, Norf H, Arndt H, Weitere M (2008) Effects of protozoan grazing within river biofilms under semi-natural conditions. Aquat Microb Ecol 52:283-296

- Wieczorek SK, Clare AS, Todd CD (1995) Inhibitory and facilitory effects of microbial films on settlement of Balanus amphitrite amphitrite larvae. Mar Ecol Prog Ser 119: 221-228

Wieczorek SK, Murray AWA, Todd CD (1996) Seasonal variation in the effects of hard substratum biofilming on settlement of marine invertebrate larvae. Biofouling 10:309-330

Submitted: August 9, 2011; Accepted: January 27, 2012 Proofs received from author(s): February 21, 2012 